\title{
プラスミンの活性中心の立体地勢の特徵
}

一一合成基質ならびに三脚型の合成阻害物質等の特性からみた——

\begin{tabular}{|c|c|c|c|c|}
\hline 彰祐 ${ }^{1)}$ & 佐々木邦子1) & 和中 & 敬子1) & 岡田 \\
\hline 津田＼cjkstart裕子2) & $\begin{array}{c}\text { 手納 直規 }{ }^{2)} \\
\text { 岡本 }\end{array}$ & $\begin{array}{l}\text { 土方 } \\
\text { 歌子5) }\end{array}$ & 明子3) & 池沢 \\
\hline
\end{tabular}

\section{The characteristics of stereogeometry at the active center of plasmin — with reference to kinetics of highly selective synthetic substrates and inhibitors-}

\author{
Shosuke OKAMOTA ${ }^{1)}$, Kuniko SASAKI ${ }^{1)}$, Keiko WANAKA ${ }^{1)}$ \\ Yoshio OKADA ${ }^{2)}$, Yuko TSUDA ${ }^{2)}$, Naoki TENO2), Akiko HIJIKATA ${ }^{3)}$, \\ Katsuko IKEZAWA4) and Utako OKAMOTO5)
}

Key words: plasmin, active center, kinetics, synthetic substrates, synthetic inhibitors

Despite of accumulated information of the LBS (lysine binding site) of the plasmin $^{1)}$, little is known of characteristic stereogeometry at the active center. The present studies were kinetically made by using selective synthetic substrates or inhibitors, with expectations that tri-pod structure of highly selective substrates and inhibitors would indicate the replica structure of the active center. From the results obtained, we conclude that the plasmin active center assumes the following three pockts; (1) the first pocket is characterized just to fit the positively charged head of the lysine residue, (2) the second is equipped with very fine structure just to fit $(2 \mathrm{R}, 4 \mathrm{R})$ structure of 4-metyle-2-piperidine-carboxylic acid, but not other stereoisomers of the above mentioned radical (Table 1), and (3) when

1）済生会兵庫県病院血栓止血研究神戸プロジェクト〔テ651 神戸市中央区日暮通 5-5-17〕, Kobe Research Projects on Thrombosis and Haemostasis, Saiseikai-Hospital, Kobe, Japan.

2) 神戸学院大学薬学部薬化学, Department of Medical Chemistry, Faculty of Pharmaceutical Science, KobeGakuin University, Kobe, Japan.

3）神戸大学医療短期大学, Kobe University School of Allied Medical Sciences, Kobe, Japan.

4）兵庫医科大学中央臨床検査部, Department of Clinical Pathology and Clinical Laboratory, Hyogo Medical College, Nishinomiya, Japan.

5) 神戸学院大学栄養学部生理, Department of Physiology, Faculty of Nutrition, Kobe-Gakuin University, Kobe, Japan. 
examined by D-Ile-L-Phe-L-Lys-pNA, 3-methyl-valeric acid-L-Phe-L-Lys-pNA and L-Ile-L-Phe-L-Lys-pNA, the third pocket is to fit (a) D-Ile-, (b) 3-methylvaleric acid-, and (c) L-Ile-, with differend $\mathrm{Km}$ values (a) $20 \mu \mathrm{M}$, (b) $180 \mu \mathrm{M}$, and (c) $330 \mu \mathrm{M}$ respectively, the highest affinity of the third pocket for the terminal D-Ile derivative being indicated (Table 2).

\section{目的}

プラスミン分子のH鎖クリングルにあるLBS (lysin binding site) の特性が注目され，いわ ゆる LBS 指向型の $\mathrm{t}-\mathrm{AMCHA}$ 等のプラスミ ン阻害物質の知見は集められつつある1)。 しか るに, プラスミンの L 鎖に位置する「活性中心」 の特性については知るところが極めてすくな い.すでにトロンビンに関しては, 多数の選択 的阻害物質が研究され れ ${ }^{2 \sim 4)}$, 高度の特異性をも ち, $\mathrm{Ki}$ が $10^{-8} \mathrm{M}$ に達する三脚型の Arg 誘導 体が得られ5)，トロンビンの活性中心は，その レプリカ構造をとるものと想定された ${ }^{6)}$.

本研究は, 第 1 にプラスミンの選択的合成基 質 ${ }^{7)}$ ならびに阻害物質の構造と作用の関係を追 求し, さらにすすんで, プラスミンの活性中心 が特に有効な阻害物質敊よび基質のレプリカ構 造をとるとする推定のもとに，その立体地勢の
特徵を検討しょうとしたものである。

\section{I. 実験材料および実験方法}

（1）合成基質または阻害物質としては，私共 が合成した L-Arg 拉よび L-Lys を一脚とする 三脚構造をもつものを多用した. 特に L-Lys をC末にもつペプチドでは，そのN末の Ile あ るいはPro に種々の化学修飾を加光, その影 響を検討した。

(2) Arg のC末に 4-methyl-2-piperidinecarboxylic acid (MPCA) が結合した化合物に 抒いては，その立体構造とプラスミン抑制作用 の関係を検討した。

(3) プラスミンは KABI 社提供の lyophilized powder (for laboratory use) を用い，活性 中心に対する阻害活性には, 注記した場合以外 は主として S-2251 を用いて測定した.

Table 1 Stereochemical structures of MD 805 and their inhibition constants for plasmin and thrombin

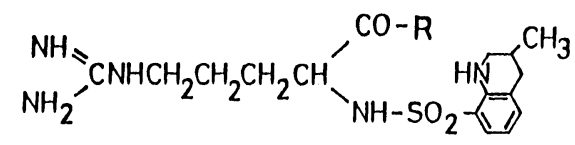

\begin{tabular}{lll}
\hline Structures of $\mathrm{R}$ & Plasmin & $\mathrm{Ki}(\mu \mathrm{M})$ \\
\hline
\end{tabular}


Table 2 Synthetic substrates and inhibitors to plasmin

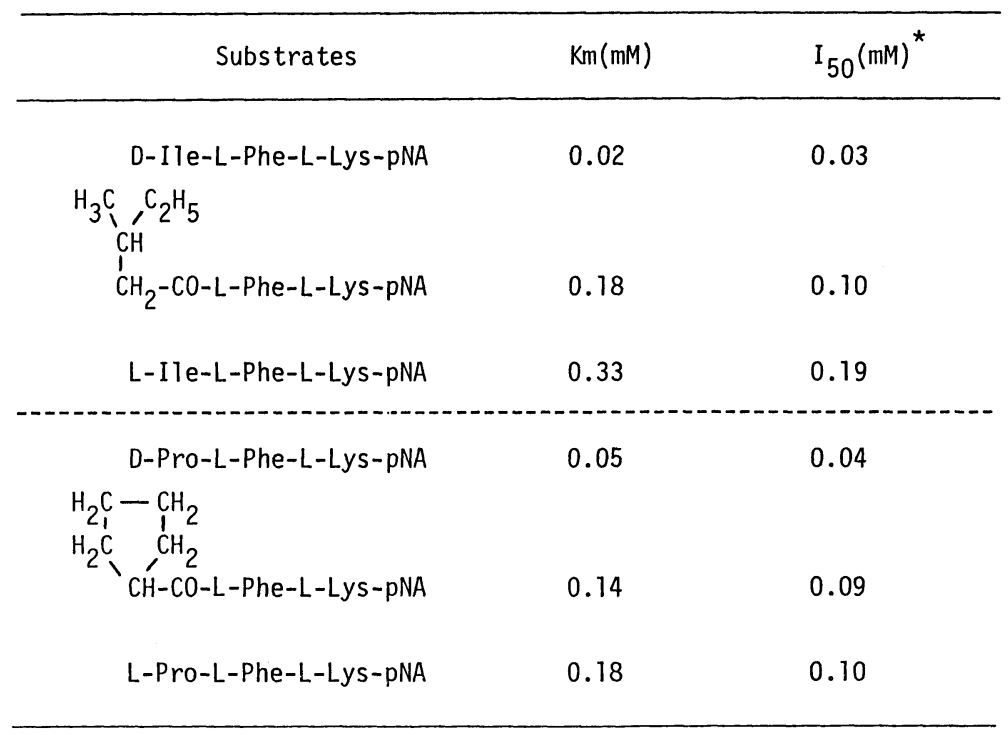

* Boc-L-Val-L-Leu-L-Lys-MCA(f.c. 0.1mM) was used as substrate.

\section{II. 成 樍}

(1) プラスミンに捛いても, Arg または Lys をもつ三脚構造が基質または阻害物質として有 効であるが，一般に Lys 誘導体は Arg のそれ よりも明かに小さな $\mathrm{Km}$ 和よび $\mathrm{Ki}$ を示した.

(2) Arg のC末に MPCA が結合した化合 物では事実上 $(2 \mathrm{R}-4 \mathrm{R})$ 構造のみ阻害 作 用 がみられた（表 1 ）。

(3) Lys の $\mathrm{N}$ 末に関しては，新しく合成さ れた D-Ile-L-Phe-L-Lys-pNA が Km $20 \mu \mathrm{M}$ kcat $\left(\mathrm{s}^{-1}\right) 10$ を示し, 在来の D-Val-L-LeuL-Lys-pNA の $\mathrm{Km} 300 \mu \mathrm{M}$, kcat $\left(\mathrm{s}^{-1}\right) 11$ に 比較して，はるかにすぐれた值を示した。 しか し，D-Ileを 3-methyl-valeric acid あるいは L-Ile に置換した場合には，Mm がそれぞれ $180 \mu \mathrm{M}$ 抢よび $330 \mu \mathrm{M}$ を示した（表 2 ).

\section{III. 考察および結論}

プラスミンの『限定分解』には，その活性中 心の『特性』も深く関与する. 活性中心には三 脚構造のレプリカ構造をとる立体地勢が存在 し, Arg 拈よび Lys のオメガアミノ基に対応 する第一ポケットの他に, Lys 等の $\mathrm{C}$ 末に相当
して，MPCA の微細な立体構造を読み取る第 二ポケットがあり，さらに Lys 等の $\alpha$ 位の $\mathrm{N}$ 末より, 数オングストロングの距離に $\mathrm{D}$ 型アミ ノ酸の「遊離アミノ基」に対応する第三ポケッ トの特性（执そらくはマイナス荷電）の存在が 推論された。

\section{文献}

1) Okamoto, S. and Hijikata, A.: Rational approach to proteinase inhibitors. Drug Design, VI; 143 199, 1975.

2) Okamoto, S., Kinjo, K., Hijikata, A., Kikumoto, R., Tamao, Y., Ohkubo, K. and Tonomura, S.: Thrombin inhibitors. 1. Ester derivatives of $\mathrm{N}^{\alpha}$-(arylsulfonyl)-L-arginine. J. Med. Chem., 23; 827 350, 1980.

3) Kikumoto, R., Tamao, Y. Ohkubo, K. Tezuka, T., Tonomura, S., Okamoto, S., Funahara, Y. and Hijikata, A.: Thrombin inhibitors. 2. Amide derivatives of $\mathrm{N}^{\alpha}$-substituted L-arginine. J. Med. Chem., 23; 830 836, 1980.

4) Kikumoto, R., Tamao, Y., Ohkubo, K., Tezuka, T., Tonomura, S., Okamoto, S. and Hijikata, A.: Thrombin inhibitors. 3. Car- 
boxyl-containing amide derivatives of $\mathrm{N}^{\alpha}-$ substituted L-arginine. J. Med. Chem., 23; 1293 1299, 1980,

5) Kikumoto, R., Tamao, Y., Tezuka, T., Tonomura, S., Hara, H., Ninomiya, K., Hijikata, A. and Okamoto, S.: Selective inhibition of thrombin by $(2 \mathrm{R}, 4 \mathrm{R})-4-$ methyl-1-[N2[(3-methyl-1, 2, 3, 4-tetrahydro-8-quinolinyl) sulfonyl] L-arginyl)]-2-piperidinecarboxylic acid. Biochemistry, 23; 85 90, 1984.

6) Hijikata, A., Okamoto, S., Kikumoto, R. and Tamao, Y.: Kinetic studies on the selectivity of a synthetic thrombin-inhibitor using synthetic peptide substrates. Thrombos. Haemostas., 42; 1039 1045, 1979.

7) Cs.-Szabó, G., Pozsgay, M. and Elödi, P.: Investigation of the substrate-binding site of human plasmin using tripeptidyl-p-nitroanilide substrates. Thromb. Res., 20; 199 206, 1980.

8) Okamoto, S., Hijikata, A., Sasaki, K., Kikumoto, R. and Tamao, Y.: Similarity and dissimilarity of stereogeometry of active center of plasmin and thrombin. Progress in $\mathrm{Fi}$ brinolysis, VI; 315 317, 1983.

\section{○白血病治療の理論亡実際! \\ 白血病の化学療法一基礎と臨床一}

編集 滋賀医科大学学長 脇坂行一 專門医28名分担執筆 A 5 判 292頁 図60 表42 定価5,800円(干300円)

白血病，とくに急性白血病といえば，輸血以外になすすべもなく手をこまねいて見てい るのが実情であった。しかし近年, 白血病の化学療法が進歩し, 白血病の治癒についても 一縷の光明が顕われてきた。本書は白血病の化学療法の理論と実際に焦点をしぼり，第一 線の研究者による熱心な討議をまとめたものである。我国の白血病の治療指針書である。

内容：〔白血病細胞の增殖異常と核酸代謝〕1.Leukemogenesisと白血病細胞のRNA dependent DNA polymerase 活性，2.白血病細胞のDNA合成系酵素活性と代謝調節，3.七トリンパ球におけるpyrimidine合成の調節，4.急性白血病 経過中の芽球動態とDNA合成能，5.七トリンパ性白血病細胞のgenetic transcription，6.白血病細胞におけるRNA合 成，7.Radioautographyによる白血病細胞増殖異常の解析，8.Non-dividing compartmentに属する白血病細胞の意義， 〔抗白血病剤の作用機序と臨床効果〕1.抗白血病剂の投与経路による効果の差異とその機序, 2. 白血病細胞における cytosine arabinoside と cyclocytidineの作用機序，3.抗白血病剤の殺細胞作用に及ぼす濃度因子と作用時間，4.急性白 血病の寛解導入, 維持ならびに寛解強化療法について, 5. 惄能道内白血病細胞の動態の解析による白血病化学療法, 6 . 慢性骨能性白血病の治療と予後, 7. 白血病治療中の白血病細胞減少曲線について。 